\title{
The Regulation of Cellular Functions by the p53 Protein: Cellular Senescence
}

\author{
Crystal A. Tonnessen-Murray, ${ }^{1}$ Guillermina Lozano, ${ }^{2}$ and James G. Jackson ${ }^{1}$ \\ ${ }^{1}$ Department of Biochemistry and Molecular Biology, Tulane School of Medicine, New Orleans, \\ Louisiana 70112 \\ ${ }^{2}$ Department of Genetics, University of Texas MD Anderson Cancer Center, Houston, Texas 77030 \\ Correspondence: jjacks8@tulane.edu
}

\begin{abstract}
Transformed cells have properties that allow them to survive and proliferate inappropriately. These characteristics often arise as a result of mutations caused by DNA damage. p53 suppresses transformation by removing the proliferative or survival capacity of cells with DNA damage or inappropriate cell-cycle progression. Cellular senescence, marked by morphological and gene expression changes, is a critical component of p53-mediated tumor suppression. In response to stress, p53 can facilitate an arrest and senescence program in cells exposed to stresses such as DNA damage and oncogene activation, preventing transformation. Senescent cells are evident in precancerous adenoma-type lesions, whereas proliferating, malignant tumors have bypassed senescence, either by p53 mutation or inactivation of the p53 pathway by other means. Tumors that have retained wild-type p53 often show a p53-mediated senescence response to chemotherapy. This response is actually detrimental in some tumor types, as senescent cells can drive relapse by persisting and producing cytokines and chemokines through an acquired secretory phenotype.
\end{abstract}

\section{SENESCENCE: A PERMANENT CELL-CYCLE ARREST IN FIBROBLASTS MEDIATED BY p53}

$p_{b}^{5}$ 53 is able to block cells with the potential to become a tumor from proliferating largely through its ability to act as a transcription factor. One of the best-characterized mechanisms of tumor suppression mediated by $\mathrm{p} 53$ is apoptotic cell death (Lowe et al. 1993; Symonds et al. 1994). It is intuitive that entirely removing a damaged cell from an organism will prevent that cell from ever becoming a tumor. More recently, accumulating evidence from biochemical studies, animal models, and clinical data has revealed that cellular senescence plays a vital role in p53-mediated tumor suppression.

Cellular senescence is a permanent cell-cycle arrest caused by stress and is accompanied by altered gene expression and morphological changes that distinguish it from terminal differentiation (Campisi 1997). It was first described by Leonard Hayflick (1965) during serial cultivation of human diploid fibroblasts (HDFs) from the lung. These normal, p53 wild-type cells cease proliferation after a fixed number of population doublings in culture. Subsequent research has shown that these normal fibroblast cells undergo telomere shortening at each divi-

Editors: Guillermina Lozano and Arnold J. Levine

Additional Perspectives on The p53 Protein available at www.perspectivesinmedicine.org

Copyright (C) 2017 Cold Spring Harbor Laboratory Press; all rights reserved; doi: 10.1101/cshperspect.a026112

Cite this article as Cold Spring Harb Perspect Med 2017;7:a026112 
C.A. Tonnessen-Murray et al.

sion (Harley et al. 1990), with the telomeres reaching a critically short stage after a fixed number of passages (Bodnar et al. 1998). Short telomeres activate a DNA-damage response, resulting in cell-cycle arrest and replicative senescence (d'Adda di Fagagna et al. 2003; von Zglinicki et al. 2005). p53 is the critical mediator of this arrest (Itahana et al. 2001). Early experiments showed that introduction of SV40 large $\mathrm{T}$ antigen resulted in bypass of the senescence and arrest response to passaging in culture (Ide et al. 1983, 1984), and cells entered a state termed "crisis." In crisis, cells continue to divide, but at a rate that is matched by apoptosis (Neufeld et al. 1987; Radna et al. 1989). Eventually, immortal clonal populations will emerge that can maintain telomere length (Neufeld et al. 1987; Counter et al. 1992).

One of the functions of SV40 large T antigen is to inactivate p53, but it also has other activities that might obscure the precise role of p53 in replicative senescence. This role was more directly shown by gene targeting of p53 in human fibroblasts. Cells with one allele targeted will spontaneously lose the second allele, avoid senescent arrest, and continue through the cell cycle into crisis with eventual emergence of immortal cell populations (Wei et al. 2003).

In addition to mediating the onset of senescence, p53 is also important for maintaining the senescent phenotype. Introduction of a p53-inactivating peptide, large $\mathrm{T}$ antigen, or p53 siRNA by lentivirus into already senescent fibroblasts causes reentry into the cell cycle and loss of features of senescence (Beausejour et al. 2003). Interestingly, this occurred in cell lines with low levels of the cell-cycle inhibitor p16. In fibroblasts with relatively higher levels of p16 at senescence, inactivation of both p53 and $\mathrm{Rb}$ were required to reverse the phenotype (Beausejour et al. 2003). In sum, these studies show that p53-mediated senescence is a barrier to genomic instability that results from telomere erosion in fibroblasts during passage in culture, ultimately preventing acquired immortality.

Telomere shortening in the absence of p53 results in DNA damage and genomic instability, eventually leading to cellular immortality. Genetically engineered mice have shown that p53 suppresses tumorigenesis in models with compromised telomeres. Mice engineered to lack telomerase activity are tumor prone, and this is accelerated by $p 53$ loss (Chin et al. 1999; Rudolph et al. 1999). Further, p53-mediated senescence suppresses tumors in mice with deprotected telomeres (Cosme-Blanco et al. 2007; Feldser and Greider 2007). Interestingly, Cdkn1a (coding for p21) deletion can extend the life span of telomerase-deficient mice, without increasing the rate of cancer by improving viability in the stem cell compartment. In these mice, p21 loss impairs p53-mediated arrest and senescence, but leaves apoptosis intact (Choudhury et al. 2007). Thus, it is clear from multiple studies that the tumor suppressor p53 plays a critical role in vivo preventing genomic instability and transformation caused by short telomeres.

\section{THE PATHWAY OF p53-MEDIATED SENESCENCE}

The mechanism of how p53 mediates the senescence program has now been defined in numerous studies. As telomeres shorten, eventually a DNA damage signal is detected (d'Adda di Fagagna et al. 2003; von Zglinicki et al. 2005) and a classical DNA damage response is initiated (von Zglinicki et al. 2005). One step in this process is the activation of the ATM kinase (Wong et al. 2003), which phosphorylates both p53 and Mdm2 (Banin et al. 1998; Canman et al. 1998; Khanna et al. 1998; Maya et al. 2001), thus allowing the p53 protein to accumulate and initiate transcription of multiple target genes (Fig. 1) (Atadja et al. 1995; Bond et al. 1996).

Among the first p53 target genes discovered was the CDKN1A gene, which codes for the cyclin-dependent kinase (cdk) inhibitor p21. p21 was discovered simultaneously as an interacting partner and inhibitor of cdks (Xiong et al. 1993), as the primary transcript elevated in a p53-dependent fashion following DNA damage (el-Deiry et al. 1993), and as the primary transcript that induces senescence in HDFs (Noda et al. 1994). Each study complemented the other and produced a remarkably complete picture of $\mathrm{p} 21$ function and regula- 


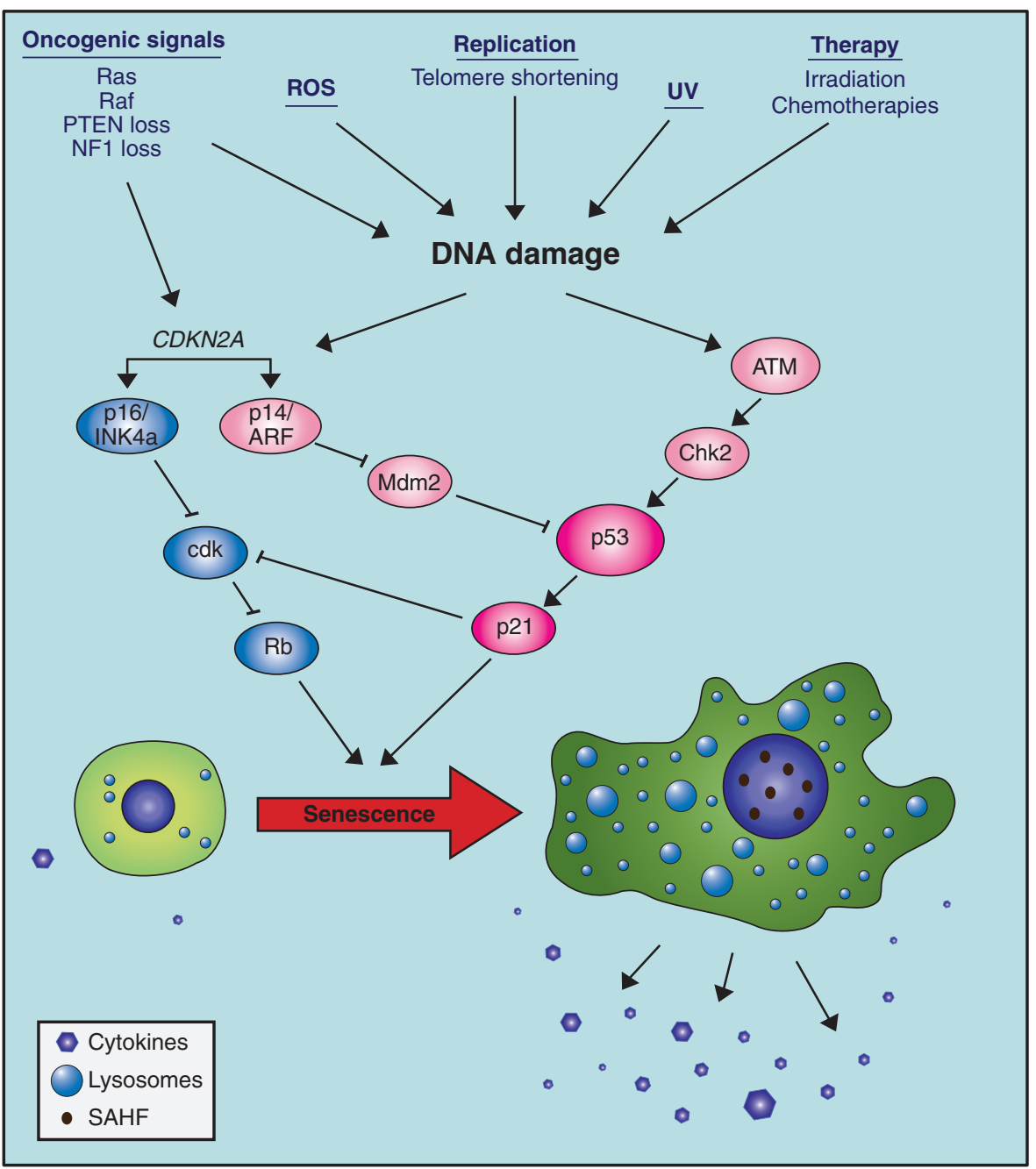

Figure 1. Mechanisms of cellular senescence. DNA damage is caused by multiple means, including oncogene activation, reactive oxygen species (ROS), cell division and replication, ultraviolet light (UV), and cancer therapies. These signals in turn can initiate p53 pathway signaling through increased ATM activity, causing Chk2-mediated phosphorylation of p53, which protects 553 from Mdm2-mediated degradation. Additionally, oncogene activation can induce ARF and p16 expression, which inhibit Mdm2 and cdk function, respectively. The resulting increased p21 and/or Rb activity can result in permanent cell-cycle arrest and senescence. Cellular senescence is marked by an enlarged, flattened morphology, increased lysosomal compartment, secretion of multiple cytokines and chemokines of the senescence-associated secretory phenotype (SASP), and sometimes formation of senescence-associated heterochromatin foci (SAHF).

tion. Subsequent studies have shown that p53 binds and transactivates the $\mathrm{p} 21$ promoter during replicative senescence of HDFs (Vaziri et al. 1997; Jackson and Pereira-Smith 2006a), and also during DNA damage induced by radiation (Jackson and Pereira-Smith 2006a). DNA damage of all sources is a potent activator of p53 and can induce senescence in many cell types (Fig. 1).

p21 helps to execute the senescence program primarily by causing cell-cycle arrest. This is achieved through inhibition of cyclin/cdk complexes, which normally phosphorylate targets that promote cell-cycle progression (Sherr 
2000). One well-studied target of cdks is the RB family of proteins (Sherr and McCormick 2002). When p21 levels are elevated via p53mediated transcription, cyclin/cdk complexes cannot phosphorylate and inhibit RB family members (Sherr 2000). This allows the RB family of proteins to recruit chromatin modifiers that silence expression of genes that drive cellcycle progression (Ferreira et al. 2001; Narita et al. 2003).

As a p53 target, p21 plays a critical role in p53-dependent senescence. Similar to cells that lack p53, normal HDFs that lack p21 also fail to arrest after serial passage (Brown et al. 1997; Herbig et al. 2004), and inactivation of p 21 by injection of specific antibodies results in reinitiation of S phase (Ma et al. 1999). Alternatively, forced expression of p21 can induce senescence when ectopically expressed in vitro (Fang et al. 1999; Chen et al. 2002). These studies define p21 as a potent mediator of p53-induced arrest and senescence in response to cell stress and DNA damage.

\section{MARKERS OF SENESCENCE}

As research expanded away from HDFs into other types of cultured cells and in vivo models, determining whether a cell was actually senescent, as opposed to temporarily arrested or differentiated, presented a challenge. "Permanent" cell-cycle arrest can be tested in vitro, but determining this in vivo is considerably more intractable as no established set of markers exists to clearly identify these cells. No single marker is universal to all senescent cells, and probably no feature other than eventual cell-cycle progression can exclude a cell from being classified as senescent (Collado and Serrano 2010; Sharpless and Sherr 2015). One can develop a degree of confidence, however, if several factors are examined concurrently to identify senescent cells (Fig. 1). These include lack of positive staining of proliferation markers (such as Ki67 or BrdU incorporation) combined with the presence of cell-cycle inhibitors (p21, p16, p15, or hypophosphorylated Rb family members). Additionally, senescent cells secrete many cytokines and chemokines, a feature known as the senes- cence-associated secretory phenotype (SASP) (Acosta et al. 2008; Coppe et al. 2008; Kuilman et al. 2008; Wajapeyee et al. 2008). Many of these genes are up-regulated in cells made senescent by diverse stimuli and of all different origins, and thus can be used as markers of senescence.

The most commonly used marker for senescent cells is positive staining of $\beta$-galactosidase at pH 6 (senescence-associated $\beta$-galactosidase, or SA- $\beta$ Gal) (Dimri et al. 1995), which takes advantage of the increased lysosomal compartment by senescent cells (Kurz et al. 2000; Lee et al. 2006). Senescent cells also form heterochromatic foci (SAHF), which mark areas of gene silencing, including those involved in cellular proliferation (Narita et al. 2003). Finally, senescent cells undergo a marked morphological change in vitro, becoming enlarged and flattened (Campisi 1997). Although there are obviously many known characteristics of senescent cells, one alone is not sufficient for positive identification. As an example of careful identification of senescence, in serial histological tissue sections of colon adenomas, senescent cells were identified by a lack of Ki67 staining combined with positive staining for p16 and the SASP factor interleukin (IL)-8, although proliferating, nonsenescent regions of the adenomas stained inversely: positive for Ki67 and negative for p16 and IL-8 (Kuilman et al. 2008). Thus, the use of multiple markers, such as those that identify proliferative arrest, expression of cdk inhibitors, and expression of SASP factors, are necessary to clearly define senescence in vivo.

\section{OTHER STRESSES THAT CAUSE SENESCENCE MEDIATED BY p53: ONCOGENE ACTIVATION}

The first cause of senescence described was a result of telomere erosion after serial passage in tissue culture (Hayflick 1965). Since then, however, many other stresses have been shown to induce senescence in normal cells. Perhaps the most relevant to tumor suppression is the induction of senescence in response to ectopically activated oncogenes (Fig. 1).

Oncogene-induced senescence (OIS) was first described by Serrano et al. in a landmark 
p53 and Cellular Senescence

study (Serrano et al. 1997). They showed that normal fibroblasts transduced with a retroviral vector-expressing oncogenic Ras undergo a short burst of proliferation, followed by the onset of a phenotype reminiscent of fibroblasts in replicative senescence. The cells exposed to activated Ras showed elevated expression of p21 and p16, hypophosphorylated Rb, cessation of BrdU incorporation, acquisition of morphological changes, and positive SA- $\beta$ Gal staining (Serrano et al. 1997). Furthermore, it was discovered that OIS in mouse cells could be avoided through additional loss of the tumor suppressor p53. Mouse embryo fibroblasts with a genetic ablation of $p 53$ bypassed the senescence response to activated Ras, and instead increased proliferation rate. The viral oncogenes used to inactivate p53 required additional $\mathrm{Rb}$ inactivation to bypass OIS (Serrano et al. 1997).

Subsequent to this study, p53 and/or Rb family-dependent OIS has been shown in numerous cell types exposed to diverse oncogenic signals (Gorgoulis and Halazonetis 2010). In addition to Ras activity, senescence can be induced in vitro in various cell types by activation of signals downstream from Ras, including B-RAF (Zhu et al. 1998; Michaloglou et al. 2005), MEK (Lin et al. 1998), AKT (Astle et al. 2012), and PIK3CA (Kim et al. 2007; Astle et al. 2012). Upstream of Ras, activation of fibroblast growth factor receptors (FGFRs) (induces p53-dependent senescence) (Ota et al. 2009) and ERBB2 (Her2/neu, p53 dependence was not examined) can induce senescence (Trost et al. 2005). Additionally, loss of negative regulators of Ras and PI3 kinase, such as neurofibromatosis type 1 (NF1) (Courtois-Cox et al. 2006) and PTEN (Chen et al. 2005; Kim et al. 2007), result in increased signaling and senescence. Other oncogenic signals such as those from c-Mos and the Bcr-Abl fusion protein can induce senescence, although p53 dependence was not examined in these studies (Bartkova et al. 2006; Wajapeyee et al. 2010).

These experiments clearly show the induction of senescence in normal cells in response to oncogene activation and the p53 and $\mathrm{Rb}$ mechanisms that often drive the response, thus creating a well-supported hypothesis that this program is tumor suppressive in vivo.

\section{IN VIVO ROLE OF p53-MEDIATED ONCOGENE-INDUCED SENESCENCE}

Evidence of the in vivo role of p53-mediated senescence in tumor suppression has come from multiple studies. Cells in mice that carry a hypomorphic $p 53$ allele greatly favor transactivation of Cdknla and arrest/senescence programs, and fail to activate apoptotic genes (Liu et al. 2004). This hypomorphic p53 protein still suppresses spontaneous tumor formation by a Cdkn1a-dependent mechanism (Liu et al. 2004; Barboza et al. 2006) and can also suppress Mycdriven lymphoma (Post et al. 2010) and pancreatic cancer (Morton et al. 2010), extending life span in all cases when compared with p53 null or mutant alleles.

These studies showed a p53-p21-senescence pathway suppresses tumor formation. However, some questions were unaddressed, including when, during the transformation from normal cell to malignant cell, does p53mediated senescence act to prevent cancer and extend life span?

Subsequent studies in mouse models and clinical specimens addressed this question, showing that cells driven to senescence by $\mathrm{p} 53$ are prevalent in arrested, premalignant adenomas, whereas the proliferating carcinoma regions of tumors lack markers of senescence (Collado and Serrano 2010). This relationship has been observed in the prostate with Pten deletion, and in the lung and mammary gland with Ras pathway activation.

Mice with $p 53$ deletion in the prostate have no tumor phenotype, whereas mice with Pten deletion develop nonlethal prostatic intraepithelial neoplasias (PIN) that are positive for SA- $\beta$ Gal, p19Arf, p53, and p21 (Chen et al. 2005). Remarkably, mice with deletion of both Pten and p53 in the prostate, however, develop invasive carcinoma that is lethal by 7 months of age. Deletion of $p 53$ allowed bypass of the senescence in response to Pten loss in the prostate, resulting in rapid tumor progression and mortality (Chen et al. 2005).

Ductal epithelial cells in the mammary gland are also sensitive to ectopic Ras signals. Sarkisian et al. used an inducible model system 
C.A. Tonnessen-Murray et al.

in which the degree of Ras activation in the mammary could be controlled (Sarkisian et al. 2007). Potent inducible activation of $\mathrm{H}-\mathrm{RasG} 12 \mathrm{~V}$ resulted in reduced mammary duct elongation in puberty followed by induction of senescence, as detected by p16, PML, and SA- $\beta$ Gal staining (Sarkisian et al. 2007). Weaker induction of Ras caused hyperplasias in a p53 heterozygous background that could occasionally progress to tumors that spontaneously up-regulated Ras signaling. These tumors also bypassed the p53 senescence response that was observed acutely following potent Ras activation by undergoing loss of the wild-type p53 allele (Sarkisian et al. 2007).

Senescence has also been detected in premalignant lesions in the lung in a K-RasV12 lung cancer model. Lung adenomas were positive for the senescence markers p16, p15, and new markers discovered in the same study, Dec1 and Dcr2 (Collado et al. 2005). Rare lesions that progressed to adenocarcinoma had bypassed senescence (Collado et al. 2005). The role of p53 (and requirement of p53 inactivation to bypass senescence) was not examined; however, other Ras models in the lung have shown (similar to Pten in prostate discussed above) that $p 53$ null alleles greatly accelerate tumor formation and progression to invasive lung cancer (Jackson et al. 2005), consistent with bypass of senescence.

In premalignant ductal lesions of murine pancreata driven by Ras activation, p53-induced senescence was detected by positive staining for SA- $\beta$ Gal, p21, and IGFBP7 (SASP factor) (Morton et al. 2010). Interestingly, senescence was induced by a single wild-type allele in the presence of a mutant $p 53$ allele ( $p 53 R 172 H)$. In mice heterozygous for mutant p53 that progress to frank malignancy, or mice homozygous for mutant $p 53, \mathrm{p} 53$ activity was not evident and senescence had been bypassed (Morton et al. 2010).

Similar results were found for B-Raf activation in mouse lung (Dankort et al. 2007; Shai et al. 2015): OIS occurs in early lesions, but subsequent deletion of $p 53$ results in acceleration and progression of tumor growth. Human melanocytic nevi with activation of the Ras pathway, via $B R A F$ mutation, were also positive for senescent markers, such as SA- $\beta$ Gal and p16, and lack of Ki67 staining, in contrast to keratinocytes in normal skin (Michaloglou et al. 2005). Similar results were observed in a mouse model of B-Raf activation in melanocytes (Dhomen et al. 2009). The role of p53 in inducing arrest and senescence was not directly addressed in these studies. However, in contrast to other models, such as lung and prostate, it does not appear that loss of p53 is required to bypass senescence and progress to malignancy in melanoma, as these tumors are predominately p53 wild-type. It is possible that the p53 pathway is inactivated by other means.

In a study that expanded our understanding of senescence and tumor suppression, Kang et al. showed that activation of oncogenic Ras in murine liver cells caused senescence, as shown by positive staining for $\mathrm{p} 21, \mathrm{p} 16$, and SA- $\beta \mathrm{Gal}$. Interestingly, these senescent cells are cleared by the immune system, and failure to do so led to development of hepatocellular carcinoma (Kang et al. 2011).

\section{THE COST OF TUMOR SUPPRESSION BY SENESCENCE}

Although the immediate consequence of p53mediated cellular senescence is tumor suppression, it is hypothesized that the accumulation of senescent cells over the course of the lifetime of an individual can result in aging phenotypes (Campisi 2005; Rodier et al. 2007). Although this theory has not been strictly proven, evidence exists suggesting the possibility it could indeed be true. Cells positive for senescence markers, such as SA- $\beta$ Gal or p16, accumulate in aged individuals (Dimri et al. 1995; Hornsby 2002). Unfortunately, reducing or eliminating activity of p53 to examine the effect on aging is not possible, as an organism with compromised p53 succumbs to tumors early in life. However, p53 loss has been shown to rescue some models of progeria and senescence.

Mice with a mutation in the Zmpste24 gene recapitulate Hutchinson-Gilford progeria and show numerous premature aging phenotypes, including cellular senescence, as detected by 
elevated expression of $\mathrm{p} 21$ in the heart and liver and SA- $\beta$ Gal staining in the kidney and other organs (Varela et al. 2005). Deletion of p53 resulted in partial rescue of the aging phenotypes. Mice null for both Zmpste24 and p53 no longer stained positive for SA- $\beta$ Gal in the kidney and had a longer life span than p53 wild-type, Zmpste24 null mice (Varela et al. 2005).

p53 can also mediate senescence in developing embryos with compromised genomic maintenance. Stress caused by homozygous loss or mutation of the DNA repair gene Brcal causes late gestation embryonic lethality in mice because of widespread senescence, as detected by extensive SA- $\beta$ Gal staining throughout the embryo as well as elevated p21 expression (Cao et al. 2003). When crossed into a p53 heterozygous null background, the developmental defects are completely rescued, no senescence is observed in the embryo, and mice can live 6 to 12 months (Cao et al. 2003). The mice do show aging phenotypes later in life, possibly because of the activity of the remaining wild-type p53 allele.

\section{WILD-TYPE p53 TUMORS: CAN SENESCENCE AFFECT RESPONSE AND OUTCOME?}

Cancer is a disease marked by uncontrolled proliferation that is commonly paired with decreased DNA repair capabilities. In the hope of exploiting these characteristics, chemotherapies that cause DNA damage are commonly used in the clinic (Gianni et al. 2009). Ideally, a rapidly proliferating cancer cell will be overwhelmed with DNA damage it cannot repair efficiently and die, whereas normal somatic cells will be able to recover. Although effective in many circumstances, especially in blood-borne cancers (Weller 1998; Zenz et al. 2008), this is not always the case. For many solid tumors, only a partial response is observed following chemotherapy, leaving significant residual disease (Weller 1998; Symmans et al. 2007). Recent studies have shown that apoptosis is not always the primary p53-mediated response to DNA damage from chemotherapy. In many cases, p53 drives arrest and senescence, resulting in incomplete eradication of the tumor.
Senescence as a response to chemotherapy can potentially be a desirable outcome. Intuitively, it makes sense that permanent cell-cycle arrest would halt tumor progression and prevent relapse. Additionally, senescent cells can be cleared from tissue by the immune system much like cells that have undergone apoptosis, leading to tumor regression (Xue et al. 2007). However, secretion of multiple cytokines and growth factors by the SASP can act via paracrine and autocrine signaling and can have protumorigenic effects on nearby cells (Velarde et al. 2013; Perez-Mancera et al. 2014). To circumvent unwanted outcomes, these competing facets of therapy-induced senescence (TIS) must be considered when designing cancer therapy strategies.

\section{DNA-DAMAGING CHEMOTHERAPY INDUCES p53-DEPENDENT CELLULAR SENESCENCE IN VITRO}

The role of p53 in inducing cellular senescence has been well documented in cancer cells as a response to chemotherapy and DNA damage. This was first described in a study in which doxorubicin, a DNA-damaging chemotherapeutic drug, was administered to multiple cancer cell lines. All cell lines with wild-type p53 showed increased SA-ßgal staining, indicative of senescence, whereas cell lines that did not become senescent were mutant for p53 and instead underwent mostly apoptosis or mitotic death (Chang et al. 1999). In subsequent studies, DNA-damaging drugs were also found to induce senescence in p53 wild-type colon, ovarian, and breast adenocarcinoma cell lines, as detected by SA-ßgal staining, increased p53, p21, p16, and hypophosphorylated Rb (te Poele et al. 2002). Additionally, this induced senescence was shown to be p53-dependent, as HCT116 colon carcinoma cell lines null for either p53 or p21 did not increase SA-ßgal staining after chemotherapy treatment (te Poele et al. 2002). MCF-7 breast cancer cells, which are wild-type for $\mathrm{p} 53$, also undergo senescence in response to doxorubicin (Elmore et al. 2002; Jackson and Pereira-Smith 2006b). This response is altered when p53 activity is compromised by expression of the HPV-16 E6 oncogene (Elmore et al. 2002) or by siRNA 
C.A. Tonnessen-Murray et al.

silencing (Jackson et al. 2012), resulting in a cell death response instead of a senescent one.

It is apparent from these in vitro studies that presence of wild-type p53 in many cancer cell lines can direct a senescent response after chemotherapy in vitro (Roninson 2002; Ewald et al. 2010). Conversely, those tumors lacking wildtype p53 activity do not senesce and instead undergo cell death, which could potentially give a more favorable initial response to chemotherapy.

\section{THERAPY-INDUCED SENESCENCE AND p53 IN VIVO}

Evidence for TIS in vivo was described by te Poele et al. (2002) in breast cancer and expanded on in other studies using more tractable mouse models. Breast cancer is rarely cured by chemotherapy, and residual disease is usually present at surgery following neoadjuvant chemotherapy (Symmans et al. 2007). Senescence was examined in samples taken from breast cancer patients that had undergone a preoperative DNA-damaging chemotherapy regimen. When compared with tumors from patients who had not received any previous treatment, there was a higher occurrence of senescence as detected by SA- $\beta$ gal and p16 staining in tumors judged to be p53 wild-type because of a lack of stabilized p53 protein (an indicator of p53 mutation) (te Poele et al. 2002).

Senescent features were also observed in human breast cancer xenografts from mice that were administered chemotherapy. Tumors wild-type for p53 had increased senescent markers after treatment, whereas those mutant for p53 did not, and instead underwent mitotic catastrophe (Varna et al. 2009), although no data on outcome were collected. Senescence was also detected following chemotherapy treatment in lymphomas driven by transgenic Myc. These tumors (and others of myeloid origin) naturally undergo apoptosis in response to chemotherapy. However, when apoptosis was blocked by ectopic $\mathrm{Bcl} 2$ expression, senescence was induced (Schmitt et al. 2002). These studies show that chemotherapy is capable of inducing p53 and senescence within tumors, but how this affects tumor response and relapse was not addressed.

\section{THERAPY-INDUCED SENESCENCE CAN POSITIVELY OR NEGATIVELY AFFECT OUTCOME AND SURVIVAL}

If senescent cells are permanently arrested following chemotherapy treatment, then theoretically senescence should be as effective a response as apoptosis. Accumulating evidence, however, suggests that senescence is actually a significantly inferior response, and senescent cells can actually drive relapse.

In a study using the MMTV-Wnt1 transgenic mouse model of mammary tumors, p53 wildtype tumors had poor response to doxorubicin administration and relapsed sooner than tumors that were mutant for p53 (Jackson et al. 2012). The p53 wild-type tumors were positive for many markers of senescence, including positive staining for SA- $\beta$ gal, negative staining for proliferation markers such as Ki67, and mRNA expression was increased for many cytokines and chemokines of the SASP (Jackson et al. 2012).

Similar results were found in another study using human-in-mouse xenografted breast tumor transplants. Triple-negative human tumors, which are often mutant for p53 and highly aggressive, were engrafted into the mammary fat pad of immune compromised mice $(\mathrm{Ma}$ et al. 2012). Tumors wild-type for p53 arrest in response to chemotherapy, resulting in a quicker relapse than mutant p53 tumors. Knockdown of p53 in the wild-type line enhanced drug sensitivity (Ma et al. 2012). A role for induction of senescence was not examined in this study, although induction of senescence in the p53 wild-type tumors would be consistent with observations in other studies (te Poele et al. 2002; Jackson et al. 2012).

A limited number of studies have examined p53 status, TIS, and outcome in human patients. In one study, senescent markers including SA- $\beta$ gal and SASP gene PAI-1 were induced following DNA-damaging chemotherapy in some human tumor samples of malignant pleural mesothelioma (Sidi et al. 2011). Those pa- 
tients with tumors that underwent senescence had less tumor regression and worse overall survival compared with those that did not undergo senescence, although p53 status was not examined (Sidi et al. 2011).

In other studies, poor response and reduced overall survival were linked with presence of wild-type p53 in both ovarian carcinoma and advanced gastric cancer (Bataille et al. 2003; Moreno et al. 2007; Wong et al. 2013). Choi et al. also showed that wild-type p53 status predicted poor response to chemotherapy in muscle-invasive bladder cancer (Choi et al. 2014). Interestingly, of the mutant p53 tumors that also showed a modest response to chemotherapy with reduced apoptosis, many had a gene signature consistent with wild-type p53 activation (Choi et al. 2014). These studies show in multiple contexts that the best responses to chemotherapy are often observed in patients with mutant p53, and that retention of wild-type p53 can result in a worse outcome, consistent with induction of arrest and senescence.

In breast cancer, how p53 affects outcome is less clear, and is dependent on what endpoint is used in the study. Approximately $30 \%$ of breast cancers carry a TP53 mutation (TCGA-Network 2012). In the neoadjuvant setting, in which chemotherapy treatment precedes surgery, the probability of achieving a complete pathological response, with no residual disease present following treatment, is much higher in TP53 mutant tumors (Bertheau et al. 2002, 2007; Chen et al. 2012; Esserman et al. 2012; Wang et al. 2015).

Although a better pathological response to chemotherapy normally predicts better overall survival, this correlation is muddled in breast cancer. The superior initial response of p53 mutant tumors to chemotherapy does not correlate with an improved outcome in the p53 mutant tumor patient population, which has either reduced or has made no difference in survival (Olivier et al. 2006; Esserman et al. 2012; Silwal-Pandit et al. 2014; Wang et al. 2015).

How a more robust response to chemotherapy fails to affect overall survival rates is confusing, but it is possible that averaging data from large patient pools of all responses is obscuring the actual story. This possibility is suggested by a study that examined p53 status, patient responses, and outcome. For breast cancer patients given neoadjuvant therapy, those with TP53 mutant tumors had a higher probability of a complete response (Bertheau et al. 2007), as was observed in the above-mentioned studies. In this study, however, patients that had a complete response were analyzed as a separate group. These patients had the best overall survival rates in the study, even compared with those with wild-type p53 tumors (Bertheau et al. 2007). Interestingly, the mutant p53 tumors with an incomplete response had a shorter overall survival than both the complete responders and wild-type p53 groups (Bertheau et al. 2007). Thus, p53 mutant tumors have both the best and the worst responses to chemotherapy based on patient survival. For breast cancer patient survival, wild-type p53-mediated TIS in a tumor is less favorable than a complete response but more favorable than an incomplete response in p53 mutant tumors. Other factors such as tumor heterogeneity will need to be explored to understand this conundrum.

\section{WHY ARE SENESCENT CELLS DETRIMENTAL TO RESPONSE?}

It is clear that in multiple cancer types the presence of senescent, p53 wild-type cells following treatment is correlated with a poor response. Although this is partly because of a lack of cell death and clearance of cells in the tumor, this is not the entire picture. Senescent cells with acquired SASP persist within the tumor and can impose protumorigenic properties on neighboring cells. It has now been thoroughly shown that many types of tumor cells made senescent by chemotherapy treatment produce cytokines and chemokines through the SASP (Coppe et al. 2008; Novakova et al. 2010; Jackson et al. 2012). Many of these cytokines and chemokines induce tumorigenic properties such as proliferation, survival, angiogenesis (Takamori et al. 2000; Dhawan and Richmond 2002; Karnoub and Weinberg 2006; Yang et al. 2006; Begley et al. 2008), and an increase in the cancer stem cell population (Achuthan et al. 2011; Cahu 
C.A. Tonnessen-Murray et al.

et al. 2012; Canino et al. 2012). Krtolica et al. (2001) showed that injection of tumor cells mixed with senescent fibroblasts cells greatly increased tumor growth in mice when compared with injections of tumor cells alone. However, another study showed that the presence of TIS cells did not increase tumor growth in prostate cancer (Ewald et al. 2008). Thus, while clearly the production of cytokines and chemokines by senescent cells fuels tumor growth, factors such as the number of senescent cells, the origin of these cells, and the quantity of the chemokines they produce will influence tumor growth.

\section{CONCLUDING REMARKS}

p53-mediated senescence convincingly contributes to both tumor suppression and response to therapy. Faced with a choice between OIS and progression during tumorigenesis or TIS and primary resistance in drug treatment, senescence is indeed a favorable outcome. However, the nature of senescent cells is to persist, and recent studies have shown that the secretory phenotype acquired by senescent cells may have detrimental effects, such as driving aging phenotypes or proliferation and survival of transformed cells. Future research investigating the choice between p53-mediated apoptosis and senescence and the fate of senescent cells in organisms (Jackson et al. 2011) will be needed to deepen our understanding of tumor suppression and drug response.

\section{ACKNOWLEDGMENTS}

The authors apologize to the many laboratories whose contributions were unable to be cited because of space limitations. The authors acknowledge funding from the Department of Defense W81XWH-14-1-0216 (J.G.J.) and the National Institutes of Health (NIH) CA82577 (G.L.).

\section{REFERENCES}

Achuthan S, Santhoshkumar TR, Prabhakar J, Nair SA, Pillai MR. 2011. Drug-induced senescence generates che- moresistant stemlike cells with low reactive oxygen species. J Biol Chem 286: 37813-37829.

Acosta JC, O’Loghlen A, Banito A, Guijarro MV, Augert A, Raguz S, Fumagalli M, Da Costa M, Brown C, Popov N, et al. 2008. Chemokine signaling via the CXCR2 receptor reinforces senescence. Cell 133: 1006-1018.

Astle MV, Hannan KM, Ng PY, Lee RS, George AJ, Hsu AK, Haupt Y, Hannan RD, Pearson RB. 2012. AKT induces senescence in human cells via mTORC1 and p53 in the absence of DNA damage: Implications for targeting mTOR during malignancy. Oncogene 31: 1949-1962.

Atadja P, Wong H, Garkavtsev I, Veillette C, Riabowol K. 1995. Increased activity of p53 in senescing fibroblasts. Proc Natl Acad Sci 92: 8348-8352.

Banin S, Moyal L, Shieh S, Taya Y, Anderson CW, Chessa L, Smorodinsky NI, Prives C, Reiss Y, Shiloh Y, et al. 1998. Enhanced phosphorylation of p53 by ATM in response to DNA damage. Science 281: 1674-1677.

Barboza JA, Liu G, Ju Z, El-Naggar AK, Lozano G. 2006. p21 delays tumor onset by preservation of chromosomal stability. Proc Natl Acad Sci 103: 19842-19847.

Bartkova J, Rezaei N, Liontos M, Karakaidos P, Kletsas D, Issaeva N, Vassiliou LV, Kolettas E, Niforou K, Zoumpourlis VC, et al. 2006. Oncogene-induced senescence is part of the tumorigenesis barrier imposed by DNA damage checkpoints. Nature 444: 633-637.

Bataille F, Rummele P, Dietmaier W, Gaag D, Klebl F, Reichle A, Wild P, Hofstadter F, Hartmann A. 2003. Alterations in p53 predict response to preoperative high dose chemotherapy in patients with gastric cancer. Mol Pathol 56: 286-292.

Beausejour CM, Krtolica A, Galimi F, Narita M, Lowe SW, Yaswen P, Campisi J. 2003. Reversal of human cellular senescence: Roles of the p53 and p16 pathways. EMBO J 22: 4212-4222.

Begley LA, Kasina S, Mehra R, Adsule S, Admon AJ, Lonigro RJ, Chinnaiyan AM, Macoska JA. 2008. CXCL5 promotes prostate cancer progression. Neoplasia 10: 244-254.

Bertheau P, Plassa F, Espie M, Turpin E, de Roquancourt A, Marty M, Lerebours F, Beuzard Y, Janin A, de The H. 2002. Effect of mutated TP53 on response of advanced breast cancers to high-dose chemotherapy. Lancet 360: $852-854$.

Bertheau P, Turpin E, Rickman DS, Espie M, de Reynies A, Feugeas JP, Plassa LF, Soliman H, Varna M, de Roquancourt A, et al. 2007. Exquisite sensitivity of TP53 mutant and basal breast cancers to a dose-dense epirubicin-cyclophosphamide regimen. PLoS Med 4: e90.

Bodnar AG, Ouellette M, Frolkis M, Holt SE, Chiu CP, Morin GB, Harley CB, Shay JW, Lichtsteiner S, Wright WE. 1998. Extension of life-span by introduction of telomerase into normal human cells. Science 279: 349-352.

Bond J, Haughton M, Blaydes J, Gire V, Wynford-Thomas D, Wyllie F. 1996. Evidence that transcriptional activation by p53 plays a direct role in the induction of cellular senescence. Oncogene 13: 2097-2104.

Brown JP, Wei W, Sedivy JM. 1997. Bypass of senescence after disruption of p21 $1^{\text {CIP1/WAF1 }}$ gene in normal diploid human fibroblasts. Science 277: 831-834. 
Cahu J, Bustany S, Sola B. 2012. Senescence-associated secretory phenotype favors the emergence of cancer stemlike cells. Cell Death Dis 3: e446.

Campisi J. 1997. The biology of replicative senescence. Eur J Cancer 33: 703-709.

Campisi J. 2005. Senescent cells, tumor suppression, and organismal aging: Good citizens, bad neighbors. Cell 120: $513-522$.

Canino C, Mori F, Cambria A, Diamantini A, Germoni S, Alessandrini G, Borsellino G, Galati R, Battistini L, Blandino R, et al. 2012. SASP mediates chemoresistance and tumor-initiating activity of mesothelioma cells. Oncogene 31: $3148-3163$.

Canman CE, Lim DS, Cimprich KA, Taya Y, Tamai K, Sakaguchi K, Appella E, Kastan MB, Siliciano JD. 1998. Activation of the ATM kinase by ionizing radiation and phosphorylation of p53. Science 281: 1677-1679.

Cao L, Li W, Kim S, Brodie SG, Deng CX. 2003. Senescence, aging, and malignant transformation mediated by $\mathrm{p} 53$ in mice lacking the Brcal full-length isoform. Genes Dev 17: 201-213.

Chang BD, Broude EV, Dokmanovic M, Zhu H, Ruth A, Xuan Y, Kandel ES, Lausch E, Christov K, Roninson IB. 1999. A senescence-like phenotype distinguishes tumor cells that undergo terminal proliferation arrest after exposure to anticancer agents. Cancer Res 59: 3761-3767.

Chen X, Zhang W, Gao YF, Su XQ, Zhai ZH. 2002. Senescence-like changes induced by expression of $\mathrm{p} 21^{\text {Waf1/Cip } 1}$ in NIH3T3 cell line. Cell Res 12: 229-233.

Chen Z, Trotman LC, Shaffer D, Lin HK, Dotan ZA, Niki M, Koutcher JA, Scher HI, Ludwig T, Gerald W, et al. 2005. Crucial role of p53-dependent cellular senescence in suppression of Pten-deficient tumorigenesis. Nature 436: 725-730.

Chen MB, Zhu YQ, Xu JY, Wang LQ, Liu CY, Ji ZY, Lu PH. 2012. Value of TP53 status for predicting response to neoadjuvant chemotherapy in breast cancer: A metaanalysis. PLoS ONE 7: e39655.

Chin L, Artandi SE, Shen Q, Tam A, Lee S-L, Gottlieb GJ, Greider CW, DePinho RA. 1999. p53 deficiency rescues the adverse effects of telomere loss and cooperates with telomere dysfunction to accelerate carcinogenesis. Cell 97: 527-538.

Choi W, Porten S, Kim S, Willis D, Plimack ER, HoffmanCensits J, Roth B, Cheng T, Tran M, Lee IL, et al. 2014. Identification of distinct basal and luminal subtypes of muscle-invasive bladder cancer with different sensitivities to frontline chemotherapy. Cancer cell 25: 152-165.

Choudhury AR, Ju Z, Djojosubroto MW, Schienke A, Lechel A, Schaetzlein S, Jiang H, Stepczynska A, Wang C, Buer J, et al. 2007. Cdkn1a deletion improves stem cell function and lifespan of mice with dysfunctional telomeres without accelerating cancer formation. Nat Genet 39: 99-105.

Collado M, Serrano M. 2010. Senescence in tumours: Evidence from mice and humans. Nat Rev Cancer 10: 51-57.

Collado M, Gil J, Efeyan A, Guerra C, Schuhmacher AJ, Barradas M, Benguria A, Zaballos A, Flores JM, Barbacid M, et al. 2005. Tumour biology: Senescence in premalignant tumours. Nature 436: 642.

Coppe JP, Patil CK, Rodier F, Sun Y, Munoz DP, Goldstein J, Nelson PS, Desprez PY, Campisi J. 2008. Senescence-as- sociated secretory phenotypes reveal cell-nonautonomous functions of oncogenic RAS and the p53 tumor suppressor. PLoS Biol 6: 2853-2868.

Cosme-Blanco W, Shen MF, Lazar AJ, Pathak S, Lozano G, Multani AS, Chang S. 2007. Telomere dysfunction suppresses spontaneous tumorigenesis in vivo by initiating p53-dependent cellular senescence. EMBO Rep 8: 497503.

Counter CM, Avilion AA, LeFeuvre CE, Stewart NG, Greider CW, Harley CB, Bacchetti S. 1992. Telomere shortening associated with chromosome instability is arrested in immortal cells which express telomerase activity. EMBO J 11: $1921-1929$.

Courtois-Cox S, Genther Williams SM, Reczek EE, Johnson BW, McGillicuddy LT, Johannessen CM, Hollstein PE, MacCollin M, Cichowski K. 2006. A negative feedback signaling network underlies oncogene-induced senescence. Cancer Cell 10: 459-472.

d'Adda di Fagagna F, Reaper PM, Clay-Farrace L, Fiegler H, Carr P, Von Zglinicki T, Saretzki G, Carter NP, Jackson SP. 2003. A DNA damage checkpoint response in telomereinitiated senescence. Nature 426: 194-198.

Dankort D, Filenova E, Collado M, Serrano M, Jones K, McMahon M. 2007. A new mouse model to explore the initiation, progression, and therapy of $B R A F^{V 600 E}$-induced lung tumors. Genes Dev 21: 379-384.

Dhawan P, Richmond A. 2002. Role of CXCL1 in tumorigenesis of melanoma. J Leukoc Biol 72: 9-18.

Dhomen N, Reis-Filho JS, da Rocha Dias S, Hayward R, Savage K, Delmas V, Larue L, Pritchard C, Marais R. 2009. Oncogenic Braf induces melanocyte senescence and melanoma in mice. Cancer Cell 15: 294-303.

Dimri GP, Lee X, Basile G, Acosta M, Scott G, Roskelley C, Medrano EE, Linskens M, Rubelj I, Pereira-Smith O, et al. 1995. A biomarker that identifies senescent human cells in culture and in aging skin in vivo. Proc Natl Acad Sci 92: 9363-9367.

el-Deiry WS, Tokino T, Velculescu VE, Levy DB, Parsons R, Trent JM, Lin D, Mercer WE, Kinzler KW, Vogelstein B. 1993. WAF1, a potential mediator of p53 tumor suppression. Cell 75: 817-825.

Elmore LW, Rehder CW, Di X, McChesney PA, JacksonCook CK, Gewirtz DA, Holt SE. 2002. Adriamycin-induced senescence in breast tumor cells involves functional p53 and telomere dysfunction. J Biol Chem 277: 35509-35515.

Esserman LJ, Berry DA, Cheang MC, Yau C, Perou CM, Carey L, DeMichele A, Gray JW, Conway-Dorsey K, Lenburg ME, et al. 2012. Chemotherapy response and recurrence-free survival in neoadjuvant breast cancer depends on biomarker profiles: Results from the I-SPY 1 TRIAL (CALGB 150007/150012; ACRIN 6657). Breast Cancer Res Treat 132: 1049-1062.

Ewald J, Desotelle J, Almassi N, Jarrard D. 2008. Drug-induced senescence bystander proliferation in prostate cancer cells in vitro and in vivo. Br J Cancer 98: 1244-1249.

Ewald JA, Desotelle JA, Wilding G, Jarrard DF. 2010. Therapy-induced senescence in cancer. J Natl Cancer Inst 102: 1536-1546.

Fang L, Igarashi M, Leung J, Sugrue MM, Lee SW, Aaronson SA. 1999. p2 $1^{\text {Wafl/Cip1/Sdil }}$ induces permanent growth arrest with markers of replicative senescence in human 
C.A. Tonnessen-Murray et al.

tumor cells lacking functional p53. Oncogene 18: 27892797.

Feldser DM, Greider CW. 2007. Short telomeres limit tumor progression in vivo by inducing senescence. Cancer Cell 11: $461-469$.

Ferreira R, Naguibneva I, Pritchard LL, Ait-Si-Ali S, HarelBellan A. 2001. The Rb/chromatin connection and epigenetic control: Opinion. Oncogene 20: 3128-3133.

Gianni L, Norton L, Wolmark N, Suter TM, Bonadonna G, Hortobagyi GN. 2009. Role of anthracyclines in the treatment of early breast cancer. J Clin Oncol 27: 4798-4808.

Gorgoulis VG, Halazonetis TD. 2010. Oncogene-induced senescence: The bright and dark side of the response. Curr Opin Cell Biol 22: 816-827.

Harley CB, Futcher AB, Greider CW. 1990. Telomeres shorten during ageing of human fibroblasts. Nature 345: $458-460$.

Hayflick L. 1965. The limited in vitro lifetime of human diploid cell strains. Exp Cell Res 37: 614-636.

Herbig U, Jobling WA, Chen BP, Chen DJ, Sedivy JM. 2004. Telomere shortening triggers senescence of human cells through a pathway involving ATM, p53, and $\mathrm{p} 21^{\mathrm{CIP} 1 \text {, but }}$ not p16 ${ }^{\mathrm{INK} 4 \mathrm{a}}$. Mol Cell 14: 501-513.

Hornsby PJ. 2002. Cellular senescence and tissue aging in vivo. J Gerontol A Biol Sci Med Sci 57: B251-B256.

Ide T, Tsuji Y, Ishibashi S, Mitsui Y. 1983. Reinitiation of host DNA synthesis in senescent human diploid cells by infection with simian virus 40. Exp Cell Res 143: 343-349.

Ide T, Tsuji Y, Nakashima T, Ishibashi S. 1984. Progress of aging in human diploid cells transformed with a tsA mutant of simian virus 40. Exp Cell Res 150: 321-328.

Itahana K, Dimri G, Campisi J. 2001. Regulation of cellular senescence by p53. Eur J Biochem 268: 2784-2791.

Jackson EL, Olive KP, Tuveson DA, Bronson R, Crowley D, Brown M, Jacks T. 2005. The differential effects of mutant p53 alleles on advanced murine lung cancer. Cancer Res 65: $10280-10288$.

Jackson JG, Pereira-Smith OM. 2006a. p53 is preferentially recruited to the promoters of growth arrest genes $p 21$ and GADD45 during replicative senescence of normal human fibroblasts. Cancer Res 66: 8356-8360.

Jackson JG, Pereira-Smith OM. 2006b. Primary and compensatory roles for RB family members at cell cycle gene promoters that are deacetylated and downregulated in doxorubicin-induced senescence of breast cancer cells. Mol Cell Biol 26: 2501-2510.

Jackson JG, Post SM, Lozano G. 2011. Regulation of tissueand stimulus-specific cell fate decisions by p53 in vivo. J Pathol 223: 127-136.

Jackson JG, Pant V, Li Q, Chang LL, Quintas-Cardama A, Garza D, Tavana O, Yang P, Manshouri T, Li Y, et al. 2012. p53-mediated senescence impairs the apoptotic response to chemotherapy and clinical outcome in breast cancer. Cancer Cell 21: 793-806.

Kang TW, Yevsa T, Woller N, Hoenicke L, Wuestefeld T, Dauch D, Hohmeyer A, Gereke M, Rudalska R, Potapova A, et al. 2011. Senescence surveillance of pre-malignant hepatocytes limits liver cancer development. Nature 479: 547-551.

Karnoub AE, Weinberg RA. 2006. Chemokine networks and breast cancer metastasis. Breast Dis 26: 75-85.
Khanna KK, Keating KE, Kozlov S, Scott S, Gatei M, Hobson K, Taya Y, Gabrielli B, Chan D, Lees-Miller SP, et al. 1998. ATM associates with and phosphorylates p53: Mapping the region of interaction. Nat Genet 20: 398-400.

Kim JS, Lee C, Bonifant CL, Ressom H, Waldman T. 2007. Activation of p53-dependent growth suppression in human cells by mutations in PTEN or PIK3CA. Mol Cell Biol 27: $662-677$.

Krtolica A, Parrinello S, Lockett S, Desprez PY, Campisi J. 2001. Senescent fibroblasts promote epithelial cell growth and tumorigenesis: A link between cancer and aging. Proc Natl Acad Sci 98: 12072-12077.

Kuilman T, Michaloglou C, Vredeveld LC, Douma S, van Doorn R, Desmet CJ, Aarden LA, Mooi WJ, Peeper DS, 2008. Oncogene-induced senescence relayed by an interleukin-dependent inflammatory network. Cell 133: 1019-1031.

Kurz DJ, Decary S, Hong Y, Erusalimsky JD. 2000. Senescence-associated $\beta$-galactosidase reflects an increase in lysosomal mass during replicative ageing of human endothelial cells. J Cell Sci 113: 3613-3622.

Lee BY, Han JA, Im JS, Morrone A, Johung K, Goodwin EC, Kleijer WJ, DiMaio D, Hwang ES. 2006. Senescenceassociated $\beta$-galactosidase is lysosomal $\beta$-galactosidase. Aging Cell 5: 187-195.

Lin AW, Barradas M, Stone JC, van Aelst L, Serrano M, Lowe SW. 1998. Premature senescence involving p53 and p16 is activated in response to constitutive MEK/MAPK mitogenic signaling. Genes Dev 12: 3008-3019.

Liu G, Parant JM, Lang G, Chau P, Chavez-Reyes A, El-Naggar AK, Multani A, Chang S, Lozano G. 2004. Chromosome stability, in the absence of apoptosis, is critical for suppression of tumorigenesis in Trp53 mutant mice. Nat Genet 36: 63-68.

Lowe SW, Schmitt EM, Smith SW, Osborne BA, Jacks T. 1993. p53 is required for radiation-induced apoptosis in mouse thymocytes. Nature 362: 847-849.

Ma Y, Prigent SA, Born TL, Monell CR, Feramisco JR, Bertolaet BL. 1999. Microinjection of anti-p21 antibodies induces senescent Hs68 human fibroblasts to synthesize DNA but not to divide. Cancer Res 59: 5341-5348.

Ma CX, Cai S, Li S, Ryan CE, Guo Z, SchaiffWT, Lin L, Hoog J, Goiffon RJ, Prat A, et al. 2012. Targeting Chk1 in p53deficient triple-negative breast cancer is therapeutically beneficial in human-in-mouse tumor models. J Clin Invest 122: $1541-1552$.

Maya R, Balass M, Kim ST, Shkedy D, Leal JF, Shifman O, Moas M, Buschmann T, Ronai Z, Shiloh Y, et al. 2001. ATM-dependent phosphorylation of Mdm2 on serine 395: Role in 553 activation by DNA damage. Genes Dev 15: $1067-1077$.

Michaloglou C, Vredeveld LC, Soengas MS, Denoyelle C, Kuilman T, van der Horst CM, Majoor DM, Shay JW, Mooi WJ, Peeper DS. 2005. BRAF ${ }^{\mathrm{E} 600}$-associated senescence-like cell cycle arrest of human naevi. Nature 436: $720-724$.

Moreno CS, Matyunina L, Dickerson EB, Schubert N, Bowen NJ, Logani S, Benigno BB, McDonald JF. 2007. Evidence that p53-mediated cell-cycle-arrest inhibits chemotherapeutic treatment of ovarian carcinomas. PLoS ONE 2: e441. 
Morton JP, Timpson P, Karim SA, Ridgway RA, Athineos D, Doyle B, Jamieson NB, Oien KA, Lowy AM, Brunton VG, et al. 2010. Mutant p53 drives metastasis and overcomes growth arrest/senescence in pancreatic cancer. Proc Natl Acad Sci 107: 246-251.

Narita M, Nunez S, Heard E, Lin AW, Hearn SA, Spector DL, Hannon GJ, Lowe SW. 2003. Rb-mediated heterochromatin formation and silencing of E2F target genes during cellular senescence. Cell 113: 703-716.

Neufeld DS, Ripley S, Henderson A, Ozer HL. 1987. Immortalization of human fibroblasts transformed by origindefective simian virus 40. Mol Cell Biol 7: 2794-2802.

Noda A, Ning Y, Venable SF, Pereira-Smith OM, Smith JR. 1994. Cloning of senescent cell-derived inhibitors of DNA synthesis using an expression screen. Exp Cell Res 211: 90-98.

Novakova Z, Hubackova S, Kosar M, Janderova-Rossmeislova L, Dobrovolna J, Vasicova P, Vancurova M, Horejsi Z, Hozak P, Bartek J, et al. 2010. Cytokine expression and signaling in drug-induced cellular senescence. Oncogene 29: $273-284$.

Olivier M, Langerod A, Carrieri P, Bergh J, Klaar S, Eyfjord J, Theillet C, Rodriguez C, Lidereau R, Bieche I, et al. 2006. The clinical value of somatic TP53 gene mutations in 1,794 patients with breast cancer. Clin Cancer Res 12: 1157-1167.

Ota S, Zhou ZQ, Link JM, Hurlin PJ. 2009. The role of senescence and prosurvival signaling in controlling the oncogenic activity of FGFR2 mutants associated with cancer and birth defects. Hum Mol Genet 18: 2609-2621.

Perez-Mancera PA, Young AR, Narita M. 2014. Inside and out: The activities of senescence in cancer. Nat Rev Cancer 14: $547-558$.

Post SM, Quintas-Cardama A, Terzian T, Smith C, Eischen CM, Lozano G. 2010. p53-dependent senescence delays E $\mu$-myc-induced B-cell lymphomagenesis. Oncogene 29: $1260-1269$.

Radna RL, Caton Y, Jha KK, Kaplan P, Li G, Traganos F, Ozer HL. 1989. Growth of immortal simian virus 40 tsA-transformed human fibroblasts is temperature dependent. Mol Cell Biol 9: 3093-3096.

Rodier F, Campisi J, Bhaumik D. 2007. Two faces of p53: Aging and tumor suppression. Nucleic Acids Res 35: 7475-7484.

Roninson IB. 2002. Tumor senescence as a determinant of drug response in vivo. Drug Resist Updat 5: 204-208.

Rudolph KL, Chang S, Lee HW, Blasco M, Gottlieb GJ, Greider C, DePinho RA. 1999. Longevity, stress response, and cancer in aging telomerase-deficient mice. Cell 96: 701-712.

Sarkisian CJ, Keister BA, Stairs DB, Boxer RB, Moody SE, Chodosh LA. 2007. Dose-dependent oncogene-induced senescence in vivo and its evasion during mammary tumorigenesis. Nat Cell Biol 9: 493-505.

Schmitt CA, Fridman JS, Yang M, Lee S, Baranov E, Hoffman RM, Lowe SW. 2002. A senescence program controlled by $\mathrm{p} 53$ and $\mathrm{p} 16^{\mathrm{INK} 4 \mathrm{a}}$ contributes to the outcome of cancer therapy. Cell 109: 335-346.

Serrano M, Lin AW, McCurrach ME, Beach D, Lowe SW. 1997. Oncogenic ras provokes premature cell senescence associated with accumulation of p53 and p16 $6^{\mathrm{INK} 4 \mathrm{a}}$ Cell 88: 593-602.

Shai A, Dankort D, Juan J, Green S, McMahon M. 2015. TP53 silencing bypasses growth arrest of BRAFV ${ }^{600 E}$-induced lung tumor cells in a two-switch model of lung tumorigenesis. Cancer Res 75: 3167-3180.

Sharpless NE, Sherr CJ. 2015. Forging a signature of in vivo senescence. Nat Rev Cancer 15: 397-408.

Sherr CJ. 2000. The Pezcoller lecture: Cancer cell cycles revisited. Cancer Res 60: 3689-3695.

Sherr CJ, McCormick F. 2002. The RB and p53 pathways in cancer. Cancer Cell 2: 103-112.

Sidi R, Pasello G, Opitz I, Soltermann A, Tutic M, Rehrauer H, Weder W, Stahel RA, Felley-Bosco E. 2011. Induction of senescence markers after neo-adjuvant chemotherapy of malignant pleural mesothelioma and association with clinical outcome: An exploratory analysis. Eur J Cancer 47: 326-332.

Silwal-Pandit L, Vollan HK, Chin SF, Rueda OM, McKinney S, Osako T, Quigley DA, Kristensen VN, Aparicio S, Borresen-Dale AL, et al. 2014. TP53 mutation spectrum in breast cancer is subtype specific and has distinct prognostic relevance. Clin Cancer Res 20: 3569-3580.

Symmans WF, Peintinger F, Hatzis C, Rajan R, Kuerer H, Valero V, Assad L, Poniecka A, Hennessy B, Green M, et al. 2007. Measurement of residual breast cancer burden to predict survival after neoadjuvant chemotherapy. J Clin Oncol 25: 4414-4422.

Symonds H, Krall L, Remington L, Saenz-Robles M, Lowe S, Jacks T, Van Dyke T. 1994. p53-dependent apoptosis suppresses tumor growth and progression in vivo. Cell 78: 703-711.

Takamori H, Oades ZG, Hoch OC, Burger M, Schraufstatter IU. 2000. Autocrine growth effect of IL-8 and GRO $\alpha$ on a human pancreatic cancer cell line, Capan-1. Pancreas 21: $52-56$.

TCGA-Network. 2012. Comprehensive molecular portraits of human breast tumours. Nature 490: 61-70.

te Poele RH, Okorokov AL, Jardine L, Cummings J, Joel SP. 2002. DNA damage is able to induce senescence in tumor cells in vitro and in vivo. Cancer Res 62: 1876-1883.

Trost TM, Lausch EU, Fees SA, Schmitt S, Enklaar T, Reutzel D, Brixel LR, Schmidtke P, Maringer M, Schiffer IB, et al. 2005. Premature senescence is a primary fail-safe mechanism of ERBB2-driven tumorigenesis in breast carcinoma cells. Cancer Res 65: 840-849.

Varela I, Cadinanos J, Pendas AM, Gutierrez-Fernandez A, Folgueras AR, Sanchez LM, Zhou Z, Rodriguez FJ, Stewart CL, Vega JA, et al. 2005. Accelerated ageing in mice deficient in Zmpste24 protease is linked to p53 signalling activation. Nature 437: 564-568.

Varna M, Lehmann-Che J, Turpin E, Marangoni E, ElBouchtaoui M, Jeanne M, Grigoriu C, Ratajczak P, Leboeuf C, Plassa LF, et al. 2009. p53 dependent cell-cycle arrest triggered by chemotherapy in xenografted breast tumors. Int J Cancer 124: 991-997.

Vaziri H, West MD, Allsopp RC, Davison TS, Wu YS, Arrowsmith CH, Poirier GG, Benchimol S. 1997. ATM-dependent telomere loss in aging human diploid fibroblasts and DNA damage lead to the post-translational activa- 
C.A. Tonnessen-Murray et al.

tion of p53 protein involving poly(ADP-ribose) polymerase. $E M B O J$ 16: 6018-6033.

Velarde MC, Demaria M, Campisi J. 2013. Senescent cells and their secretory phenotype as targets for cancer therapy. Interdiscip Top Gerontol 38: 17-27.

von Zglinicki T, Saretzki G, Ladhoff J, d'Adda di Fagagna F, Jackson SP. 2005. Human cell senescence as a DNA damage response. Mech Ageing Dev 126: 111-117.

Wajapeyee N, Serra RW, Zhu X, Mahalingam M, Green MR 2008. Oncogenic BRAF induces senescence and apoptosis through pathways mediated by the secreted protein IGFBP7. Cell 132: 363-374.

Wajapeyee N, Wang SZ, Serra RW, Solomon PD, Nagarajan A, Zhu X, Green MR. 2010. Senescence induction in human fibroblasts and hematopoietic progenitors by leukemogenic fusion proteins. Blood 115: 5057-5060.

Wang Y, Xu Y, Chen J, Ouyang T, Li J, Wang T, Fan Z, Fan T, Lin B, Xie Y. 2015. TP53 mutations are associated with higher rates of pathologic complete response to anthracycline/cyclophosphamide-based neoadjuvant chemotherapy in operable primary breast cancer. Int J Cancer 138: $489-496$.

Wei W, Herbig U, Wei S, Dutriaux A, Sedivy JM. 2003. Loss of retinoblastoma but not p16 function allows bypass of replicative senescence in human fibroblasts. EMBO Rep 4: $1061-1065$.

Weller M. 1998. Predicting response to cancer chemotherapy: The role of p53. Cell Tissue Res 292: 435-445.
Wong KK, Maser RS, Bachoo RM, Menon J, Carrasco DR Gu Y, Alt FW, DePinho RA. 2003. Telomere dysfunction and Atm deficiency compromises organ homeostasis and accelerates ageing. Nature 421: 643-648.

Wong KK, Izaguirre DI, Kwan SY, King ER, Deavers MT, Sood AK, Mok SC, Gershenson DM. 2013. Poor survival with wild-type TP53 ovarian cancer? Gynecol Oncol 130: 565-569.

Xiong Y, Hannon GJ, Zhang H, Casso D, Kobayashi R, Beach D. 1993. p21 is a universal inhibitor of cyclin kinases. Nature 366: 701-704.

Xue W, Zender L, Miething C, Dickins RA, Hernando E, Krizhanovsky V, Cordon-Cardo C, Lowe SW. 2007. Senescence and tumour clearance is triggered by p53 restoration in murine liver carcinomas. Nature 445: 656660.

Yang X, Lu P, Fujii C, Nakamoto Y, Gao JL, Kaneko S, Murphy PM, Mukaida N. 2006. Essential contribution of a chemokine, CCL3, and its receptor, CCR1, to hepatocellular carcinoma progression. Int J Cancer 118: 18691876.

Zenz T, Benner A, Dohner H, Stilgenbauer S. 2008. Chronic lymphocytic leukemia and treatment resistance in cancer: The role of the p53 pathway. Cell Cycle 7: 3810-3814.

Zhu J, Woods D, McMahon M, Bishop JM. 1998. Senescence of human fibroblasts induced by oncogenic Raf. Genes Dev 12: 2997-3007. 


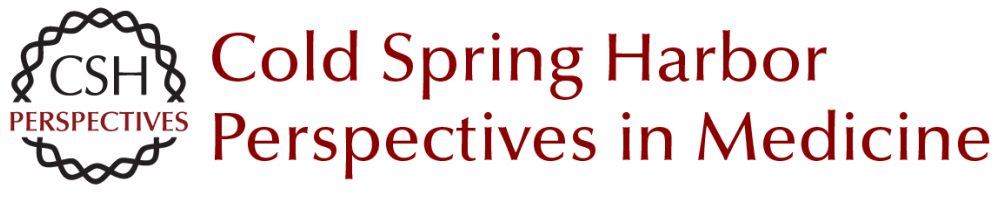

\section{The Regulation of Cellular Functions by the p53 Protein: Cellular Senescence}

Crystal A. Tonnessen-Murray, Guillermina Lozano and James G. Jackson

Cold Spring Harb Perspect Med 2017; doi: 10.1101/cshperspect.a026112 originally published online November 23, 2016

\section{Subject Collection The p53 Protein}

Targeting the MDM2-p53 Protein-Protein Interaction for New Cancer Therapy: Progress and Challenges

Shaomeng Wang, Yujun Zhao, Angelo Aguilar, et al.

Structural Evolution and Dynamics of the p53 Proteins

Giovanni Chillemi, Sebastian Kehrloesser, Francesca Bernassola, et al.

Exploiting the p53 Pathway for Therapy Chit Fang Cheok and David Philip Lane

The Regulation of Cellular Functions by the p53 Protein: Cellular Senescence Crystal A. Tonnessen-Murray, Guillermina Lozano and James $G$. Jackson

The Transactivation Domains of the p53 Protein Nitin Raj and Laura D. Attardi

The Evolution of the Ribosomal Protein-MDM2p53 Pathway

Chad Deisenroth, Derek A. Franklin and Yanping Zhang

Somatic TP53 Mutations in the Era of Genome Sequencing Pierre Hainaut and Gerd P. Pfeifer

The Paradox of p53: What, How, and Why? Yael Aylon and Moshe Oren
Control of Cellular Aging, Tissue Function, and Cancer by p53 Downstream of Telomeres Caitlin M. Roake and Steven E. Artandi

Inherited TP53 Mutations and the Li -Fraumeni Syndrome

Tanya Guha and David Malkin

TP53 Mutations in Hypodiploid Acute Lymphoblastic Leukemia

Evan Q. Comeaux and Charles G. Mullighan

Transcriptional Regulation by Wild-Type and

Cancer-Related Mutant Forms of p53

Neil T. Pfister and Carol Prives

The Inherited p53 Mutation in the Brazilian

Population Maria Isabel Achatz and Gerard P. Zambetti

TP53 Mutations in Breast and Ovarian Cancer Laxmi Silwal-Pandit, Anita Langerød and Anne-Lise Børresen-Dale

p53 and the Carcinogenicity of Chronic Inflammation

Andrei V. Gudkov and Elena A. Komarova

Oncogenic Mutant p53 Gain of Function

Nourishes the Vicious Cycle of Tumor

Development and Cancer Stem-Cell Formation

Yoav Shetzer, Alina Molchadsky and Varda Rotter

For additional articles in this collection, see http://perspectivesinmedicine.cshlp.org/cgi/collection/ 